\title{
Bacteria in coral reef water types: removal of cells, stimulation of growth and mineralization
}

\author{
Gert Jan Gast ${ }^{1, *}$, Saskia Wiegman ${ }^{2}$, Elze Wieringa ${ }^{2}$, Fleur C. van Duyl ${ }^{1}$, \\ Rolf P. M. Bak ${ }^{1,2}$ \\ ${ }^{1}$ Netherlands Institute for Sea Research, PO Box 59, 1790 AB Den Burg, The Netherlands \\ ${ }^{2}$ Institute of Systematics and Population Biology, University of Amsterdam, PO Box 94766, 1090 GT Amsterdam, \\ The Netherlands
}

\begin{abstract}
Water samples were collected at a fringing coral reef in overlying water, in bottom water between corals and in crevices under coral colonies, and analyzed for nutrient concentrations, bacterial numbers and production. We found decreasing bacterial densities from overlying water through bottom water into crevices (range 9 to $2 \times 10^{5} \mathrm{ml}^{-1}$ ). Bacterial specific growth was enhanced in reef crevices (range 0.005 to $0.04 \mathrm{~h}^{-1}$ ). Although bacterial growth was enhanced, bacterial numbers were reduced, showing a transfer of bacterial biomass into the reef. The differences in bacterial numbers and growth between water types depended on water movement and bottom relief Nutrients were enhanced in reef crevices as a result of mineralization. Mineralization of bacterta removed by fiiterfeeders could contribute 11 and $21 \%$ to the increase in $N$ and $P$, respectively, in coral reef crevices.
\end{abstract}

KEY WORDS: Bacteria $\cdot$ Nutrients Coral $\cdot$ Reef $\cdot$ Crevice

\section{INTRODUCTION}

Bacteria constitute a significant amount of biomass in pelagic ecosystems (Fenchel 1988, Bjernsen \& Kuparinen 1991). Bacteria in the water column over coral reefs are potentially an important food source for the benthos (Moriarty et al. 1985a, b. Linley \& Koop 1986, Ducklow 1990, Sorokin 1990, 1993, Ayukai 1995, Torréton \& Dufour 1996b, Hatcher 1997, Ferrier-Pagès \& Gattuso 1998). Sponges filter bacteria efficiently from the water column (Reiswig 1975, Pile et al. 1997) and coral species can consume bacteria in varying degrees (Bak unpubl. data, Sorokin 1973). Bacterivory by reef benthos may lead to a decrease in bacterial abundances in reef waters; on the other hand, bacterial growth can be stimulated in the reef water column, e.g. by coral mucus excretion (Herndl \& Velimirov 1986, Paul et al. 1986, Schiller \& Herndl 1989, FerrierPagès \& Gattuso 1998), which could lead to increases in bacterial numbers.

\footnotetext{
·E-mail: gjgast@dds.nl
}

We studied patterns of bacterial abundances and growth in different water types within what is commonly called reef water: the water column overlying the reef, the bottom water layer between coral colonies, and water in crevices between and under coral colonies. We hypothesized that, compared to the overlying water, decreases in bacterial abundances (by filtration) and increases in specific bacterial growth rates (by enhanced food supply) would occur in bottom water. Within that reef bottom water layer we distinguished water between coral colonies from water in crevices between and under coral colonies, for 2 reasons: firstly, because walls of reef crevices are inhabited by cryptofaunal filter feeders, such as clionids and other sponges; secondly, because water residence times are longer in crevices, which would give bacteria extended time to use enhanced food supplies. We expected to find an increasing benthic influence on bacteria going from overlying water at $2 \mathrm{~m}$ depth, to bottom water between corals, to reef crevices.

We included inorganic nutrients in this study to compare the different water types. As heterotrophic filter feeders oxidize most of the organic carbon they con- 
sume, they release the surplus of nutrients into their surroundings. For example, sponges excrete significant amounts of nutrients (Pile 1996, Diaz \& Ward 1997). We expected nutrient concentrations to be elevated in reef crevices, where filter feeders abound and where mixing with the surrounding bottom water is relatively low, and possibly in bottom water when water movement is reduced.

The development of these gradients would depend on the spatial structure of the reef. A high bottom relief is a characteristic of well-developed reefs with large coral colonies. Large corals increase reef bottom roughness and friction, and thereby enhance the extent of the reef bottom water boundary layer. Such well-developed reefs have many and deep crevices under and/or between coral colonies. We selected relatively healthy, undisturbed reefs with a high cover of large colonies and reefs that have for decades been influenced by anthropogenic disturbance. The latter are degraded and coral cover, number of species and colony sizes are reduced. We expected to find more pronounced differences in bacterial and nutrient characteristics between the 3 reef water types at the well-developed reef sites.

\section{METHODS}

Sample sites. We sampled at 5 stations along the leeward reefs of the island Curaçao $\left(12^{\circ} \mathrm{N}, 69^{\circ} \mathrm{W}\right)$, which are in varying degrees subject to anthropogenic disturbances such as eutrophication and sedimentation (Fig. 1). The tidal difference at Curaçao varies between 10 and $30 \mathrm{~cm}$. This does not lead to important tidal currents on the reefs, but causes a flow of heavily eutrophied bay water out of the harbour with ebb tide. Station names and reef composition are used as in the reef atlas of Curaçao and Bonaire (van Duyl 1985).

Stn 1 (Lagun Jan Thiel) is a reef site east and upcurrent of the urbanized area. The reefs are well developed, with high coral cover, high diversity and large colonies (>1 m) of species such as Montastraea annularis.

Stn 2 (Avila Beach Hotel) is a pollution affected reef site. There are various sewage outlets. The reef is dominated by a mixed assemblage of head corals $(<50 \mathrm{~cm})$ and soft corals. Diversity and coral cover are reduced.

Stn 3 (Holiday Beach Hotel) is $1 \mathrm{~km}$ downcurrent of the heavily polluted harbour (Buth $\&$ Ras 1992, Gast et al. unpubl.). The reef community is degenerated and consists mainly of small head and soft corals standing loosely in the sand and rubble.
Stn 4 (Carmabi reef, Buoy 1) is just beyond the limits of the town and the major pollution sources (Buth \& Ras 1992, Gast et al. unpubl.). The reef is moderately well developed with some large colonies (>1 m).

Stn 5 (Pestbaai). This reef is about $12 \mathrm{~km}$ west and downcurrent of the urbanized area. The reefs are moderately developed, large coral colonies alternating with patches of sand.

Sampled water types. Samples were collected using syringes $(750 \mathrm{ml})$ with a silicon tube on the tip. The open water samples were taken with a 51 Niskin bottle. We sampled:

(1) Open oceanic water at $8 \mathrm{~m}$ depth, $300 \mathrm{~m}$ off the reef (water depth over $100 \mathrm{~m}$ ).

(2) Overlying water at $2 \mathrm{~m}$ depth, 4 to $6 \mathrm{~m}$ above the reef bottom.

(3) Bottom water between the coral colonies, defined as the water layer from the bottom to the tops of the largest colonies at 6 to $8 \mathrm{~m}$ depth.

(4) Crevices under corals or narrow spaces between coral colonies (e.g. between heads of Montastraea annularis) at 6 to $8 \mathrm{~m}$ depth. There was large variatinn in size (10 to $50 \mathrm{~cm}$ deep) and shape of crevices, which depended largely on the 3-dimensional development of the reef. We preferably chose dead-end tunnels with a vertical opening and without sediment on the bottom, but this was not always possible. For example, at Stn 3 corals are so thinly spread that we often had to sample gaps under single colonies rather than tunnels

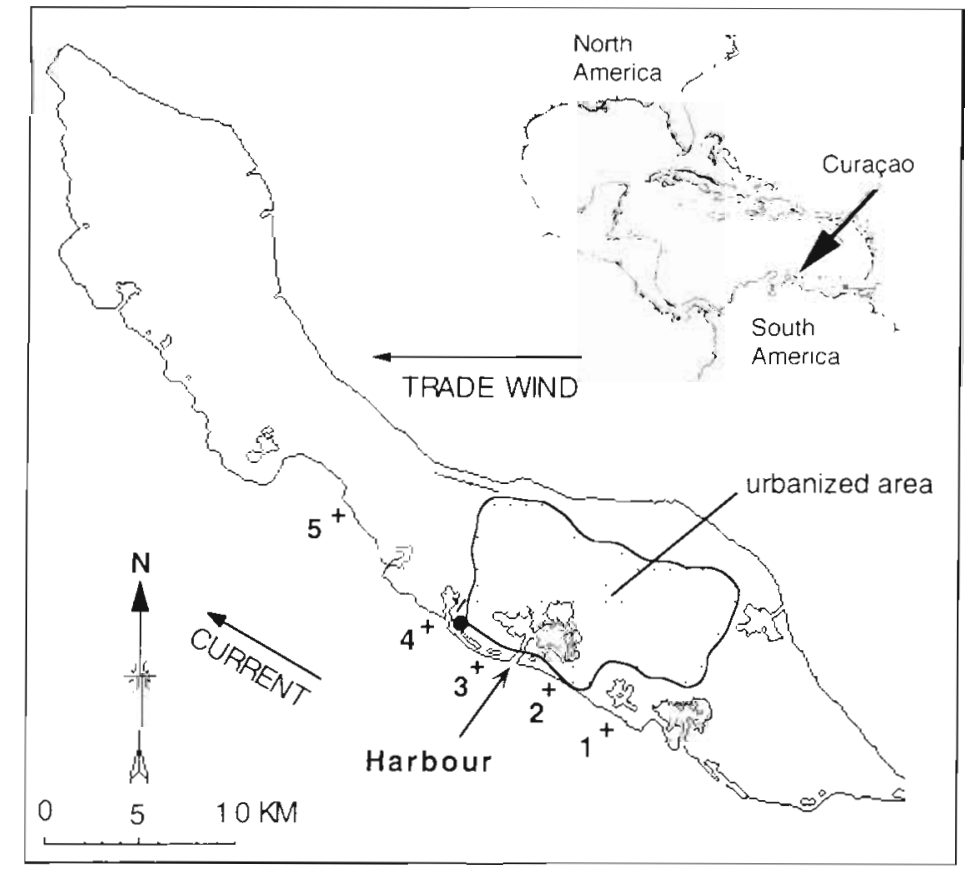

Fig. 1. Curaçao, showing locations of sampling stations. Harbour: mouth of the channel to the inner bay surrounded by urbanized area 
between colonies. To obtain an average sample from the range of crevices and to prevent pulling bottom water through the crevice into the syringe, the syringe was filled with small volumes from ca 10 crevices.

Bacterial production. Triplicate subsamples $(10 \mathrm{ml})$ for bacterial production were incubated within $30 \mathrm{~min}$ after sampling in situ at $2 \mathrm{~m}$ depth in $20 \mathrm{ml}$ Econo Glass vials (Packard Canberra) with $30 \mathrm{nmol} \mathrm{l}^{-1}$ final concentration leucine of which $10 \%$ was tritiated (L- $[3,4,5$ ${ }^{3} \mathrm{H}(\mathrm{N}) \mathrm{j}$-leucine, 143 to $168 \mathrm{Ci} \mathrm{mmol}{ }^{-1}$, New England Nuclear) for 40 to $70 \mathrm{~min}$. A control was fixed with buffered (sodium tetraborate, $\mathrm{pH}=7.9$ ), $0.2 \mu \mathrm{m}$ filtered formaldehyde (final concentration $0.7 \%$ ) before leucine addition. We extracted according to Simon \& Azam (1989), except that we rinsed the vial once with $2 \mathrm{ml} 5 \%$ TCA after the sample was poured on the filter and the chimney and filter were washed 4 times with $2 \mathrm{ml} \mathrm{5 \%}$ TCA and twice with $2.5 \mathrm{ml}$ filter-sterilized $(0.2 \mu \mathrm{m})$, formaline fixed $(2 \%)$ sea water (we established by testing that less washing with TCA and sea water resulted in higher DPM; more washing did not further reduce the counts). The filters were transferred into $6 \mathrm{ml}$ miniature vials (Canberra Packard) and $5 \mathrm{ml}$ filtercount (Canberra Packard) was added. The vials were stored cool and dark for at least $6 \mathrm{~h}$ before counting. The vials were vortexed before counting to completely dissolve the filter. Radioactivity of the samples was counted with a Rack Beta scintillation counter, with an external standard to correct for quenching.

Specific growth rates $\left(\mathrm{h}^{-1}\right)$ on a per-cell basis were calculated by converting the leucine incorporation (nmol $\mathrm{l}^{-1}$ $\mathrm{h}^{-1}$ ) with a conversion factor (cells $\mathrm{mol}^{-1}$ ) to cell production (cells $\mathrm{l}^{-1} \mathrm{~h}^{-1}$ ) and subsequently dividing cell production by cell number (cells $\mathrm{l}^{-1}$ ). The conversion factor was $7.0 \times 10^{16} \mathrm{~mol}^{-1}$ incorporated leucine, assessed for the reef waters of Curaçao (Gast et al. unpubl.).

Bacterial numbers. Duplicate subsamples $(10 \mathrm{ml})$ for bacterial numbers were fixed with buffered (sodium tetraborate, $\mathrm{pH}=7.9), 0.2 \mu \mathrm{m}$ filtered formaldehyde (final concentration $2 \%$ ) in $16 \mathrm{ml}$ polystyrene tubes (Falcon) and after staining with acridine orange $\left(100 \mathrm{mg} \mathrm{l}^{-1}\right.$ final concentration), filtered onto $25 \mathrm{~mm} 0.2 \mu \mathrm{m}$ polycarbonate filters (Nuclepore) (Hobbie et al. 1977). We counted samples (epifluorescence microscopy, Zeiss Axiophot) on a grid $(36 \mu \mathrm{m})$ divided into 10 rows and columns. At least 10 grids with at least 200 cells were counted per slide. We estimated cell sizes relative to the grid, i.e. $0.1,0.2$, $0.33,0.5$, etc., of the grid length.

Nutrients. Four ponyvials (Packard Canberra) were filled with 4 to $5 \mathrm{ml} 0.2 \mu \mathrm{m}$ fil- tered (Acrodisc) water from each sample. Samples were kept cool and stored frozen $\left(-20^{\circ} \mathrm{C}\right)$ immediately after arrival in the lab. Concentrations of ammonium (Helder \& Vries 1979), phosphate (Murphy \& Riley 1962) and nitrite/nitrate (Grasshoff 1983) were measured on a Traacs 800 auto-analyzer (Technicon) by Lab 460, Quasimeme Intercalibration Program, European Union.

Statistical analysis. All statistical methods are according to Sokal \& Rohlf (1995). In June 1994 we took at least 4 samples of each water type at the same site, and compared them using 1-way ANOVA (see Fig. 2) In 1995, when different sites were sampled on different days, we chose $t$-tests for paired comparisons between water types to exclude the place and time effects (see Figs. 2 to 5). In comparisons of the differences between crevices and bottom water in dissolved inorganic nitrogen (DIN) and phosphate and in bacterial numbers (see Fig. 6) correlation analysis was applied, because there was no a priori causative mechanism that made one variable dependent on another.

\section{RESULTS}

\section{Bacteria}

June 1994, Stn 4. Bacterial numbers decreased from overlying water at $2 \mathrm{~m}$ depth to bottom water between the corals and even more so in reef crevices (Fig. 2, $x$-axis, black symbols). The 3 water types differed significantly in bacterial abundance (ANOVA, $F=47$,

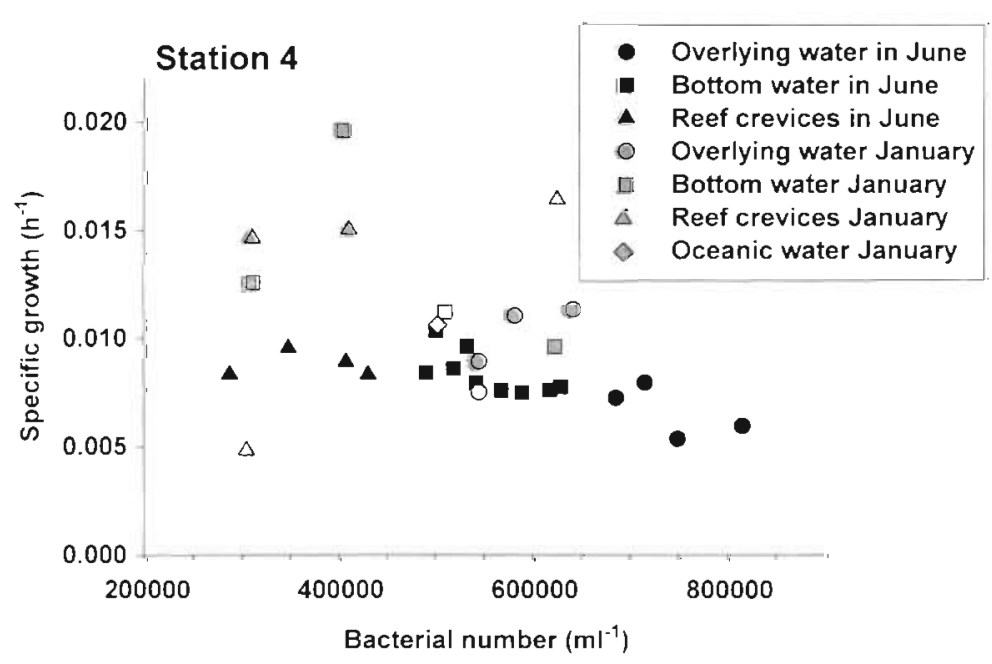

Fig. 2. Bacterial numbers ( $x$-axis) and specifıc growth rates ( $y$-axis) at $\operatorname{Stn} 4$ in June 1994 and January 1995 in overlying water at $2 \mathrm{~m}$ depth, in bottom water and in reef crevices. Duplicate samples on 14 January are both shown. Each data point consists of mean values of triplicate production measurements and duplicate counts of numbers 

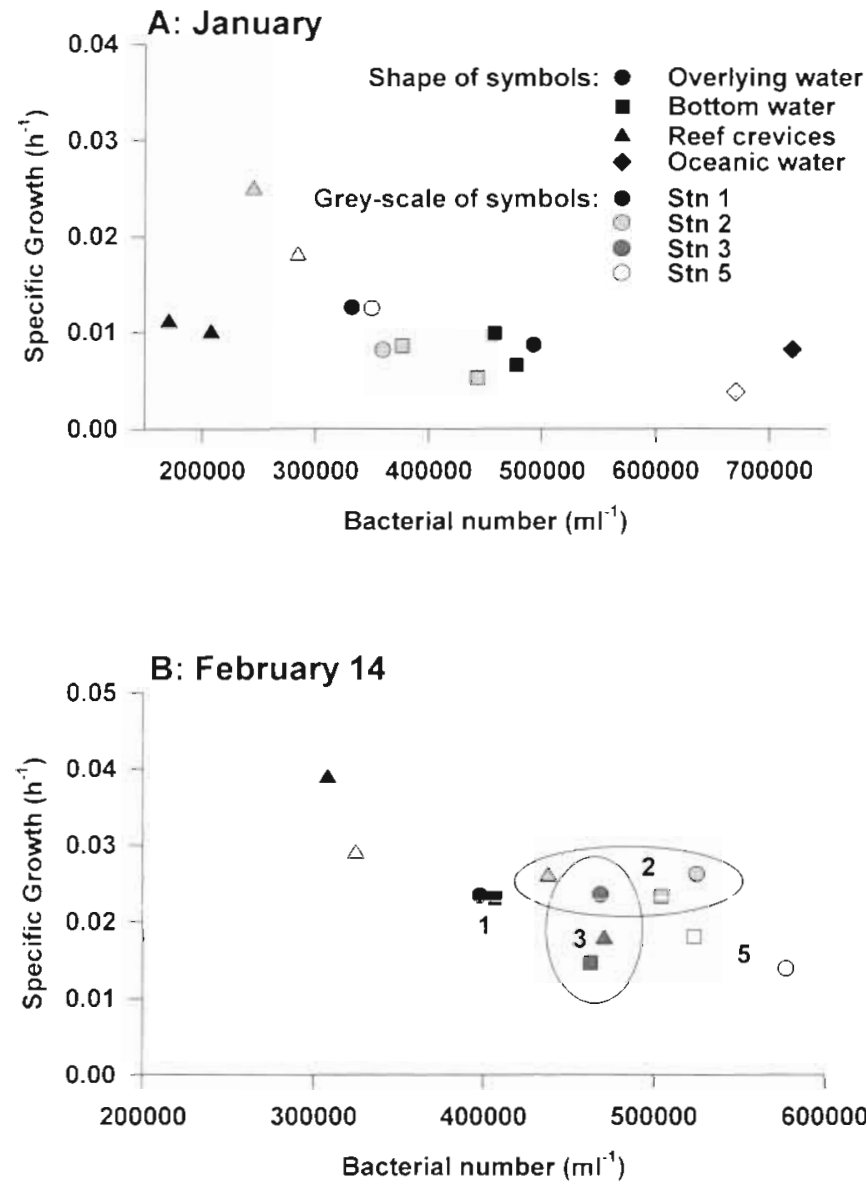

Fig. 3. Bacterial numbers and specific growth rates in January 1995 (A, Stns 1 and 2 ; each in duplicate, which are both shown) and February 1995 (B, Stns 1, 2, 3 and 5; single samples) in overlying water at $2 \mathrm{~m}$ depth, in bottom water and in reef crevices. Numbers indicate stations (Fig. 1). Each data point is the mean value of triplicate production measurements and duplicate counts of numbers

Tukey post hoc comparisons p's $<0.001$ ). Specific growth rates were the same in bottom water and crevices, but significantly lower in the overlying water (Fig. 2, $y$-axis; ANOVA, $F=6$, Tukey post hoc comparisons $\mathrm{p}<0.03$ ).

January 1995, Stn 4. The same patterns were observed, but less consistently (Fig. 2, grey symbols). In the overlying water bacterial numbers and specific growth rates were constant over $5 \mathrm{~d}$ (Fig. 2, grey circles) and the same in the adjacent oceanic open water (Fig. 2, grey diamond). In bottom water between the corals, the pattern of decreased numbers and increased specific growth was recognized in 2 out of 4 cases. Crevices were always different from overlying water, with 2 exceptions to the general pattern: one in which specific growth was decreased and another in which the numbers were equal to bottom and overlying reef water (Fig. 2). Although there was much vari- ation between dates and sites, the general pattern was a division at ca $4.5 \times 10^{5}$ bacteria $\mathrm{ml}^{-1}$, with values in reef crevices below and values in the other water types above this number (Fig. 2).

January and February 1995, Stus 1, 2, 3, 5. In January (Stns 1,2), there was a clear decrease in bacterial number from the adjacent oceanic water to waters over the reefs (Fig. 3A). We found considerable variation in bacterial densities in overlying water and in bottom water between duplicates, but bacterial numbers were clearly decreased in reef crevices (Fig. 3A). In February, low numbers and high growth rates occurred in reef crevices compared to the ambient bottom water at Stns 1 and 5 (Fig. 3B), but no change was observed at Stns 2 and 3 . We lumped the data collected at the various sites in January and compared crevices to overlying water: bacterial numbers were significantly lower ( $t$-test for paired comparisons: $t=3.2, p<0.05)$ and doubling times (low outlier excluded) were significantly shorter ( $t$-test for paired comparisons: $t=2.7, \mathrm{p}<$ $0.05)$ in crevices.

February to April 1995, Stns 1, 2, 3, 5. Bacterial numbers were significantly lower in crevices than in bottom water and overlying water at Stns 1,2, 3 and 5 over 3 mo (Fig. $4 ; t$-test for paired comparisons: $t$ 's $>4$, p's $<0.03$ ). Although observed at all 4 sites, this pattern was the least clear at the least developed reef (Stn 3). There was never a difference in bacterial density between bottom water and overlying water at $2 \mathrm{~m}$ depth.

We estimated bacterial cells in size classes under the microscope. In none of our studies could we discern a decrease in any particular size range of bacteria, e.g. larger cells, in bottom water or crevices. When there was a reduction in numbers, all size classes decreased equally.

\section{Nutrients}

In January 1995 ammonium, nitrite, nitrate and phosphate were enhanced in crevices at most stations (Fig. 5). Stns 2 and 5 showed smaller and less consistent differences. The high concentrations of ammonium and nitrite at Stn 3 originated from highly polluted harbour water flowing along the coast with the outgoing tide. (The harbour water has very high concentrations of these nutrients; Gast et al. unpubl.). All 5 stations lumped together showed significant increases for all nutrients, except $\mathrm{NH}_{4}{ }^{-}$, in crevices compared to bottom water [ $t$-test for paired comparisons: $t=0.3,4.8$, $3.3,2.8,3.6, \mathrm{p}=0.76,0.0003,0.006,0.016$ and 0.0033 for $\mathrm{NH}_{4}^{-}, \mathrm{NO}_{2}^{-}, \mathrm{NO}_{3}^{-}, \mathrm{DIN}\left(\mathrm{NH}_{4}^{-}+\mathrm{NO}_{2}^{-}+\mathrm{NO}_{3}^{-}\right)$and $\mathrm{PO}_{4}{ }^{3}{ }^{3}$, respectively].

The differences between crevices and bottom water in DIN and $\mathrm{PO}_{4}{ }^{3-}$ were significantly correlated $(\mathrm{r}=$ 


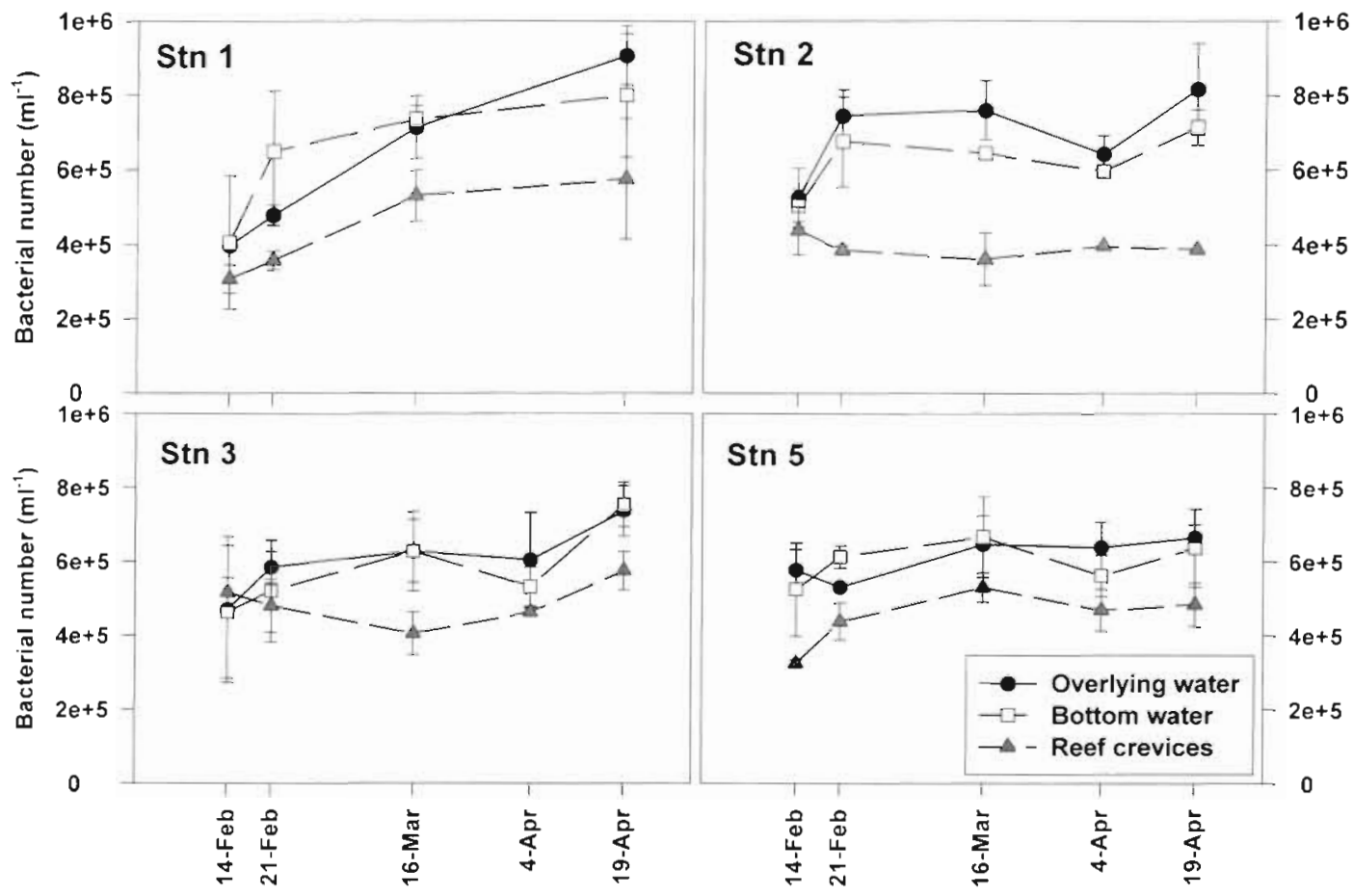

Fig. 4. Bacterial numbers in February to April 1995 at Stns 1,2, 3 and 5 (see Fig. 1) in overlying water at $2 \mathrm{~m}$ depth, bottom water and in reef crevices. Each point is the average of 2 samples taken $50 \mathrm{~m}$ apart (duplicate counts of numbers in each sample); bars show SE of samples

$0.80, \mathrm{n}=14$ ) in a molar ratio of ca 24 (Fig. 6A). An increase in DIN co-occurred with an increase in $\mathrm{PO}_{4}{ }^{3-}$ When bacterial numbers were low in crevices, DIN and $\mathrm{PO}_{4}{ }^{3-}$ were increased (Fig. 6B). The increases in DIN and $\mathrm{PO}_{4}{ }^{3-}$ were significantly correlated to the decrease in bacterial numbers (DIN $\mathrm{r}=0.87, \mathrm{PO}_{4}{ }^{3-} \mathrm{r}=$ $0.60, n=12$ ). Although in a few cases the number of bacteria was higher in crevices than in bottom water (ratio < 1), a strong decrease in bacterial numbers cooccurred with a strong increase in nitrogen and phosphate.

\section{DISCUSSION}

\section{Bacterial numbers}

At Curaçao, bacterial numbers at $2 \mathrm{~m}$ depth in oceanic and reef water varied between 5 and $15 \times$ $10^{5} \mathrm{ml}^{-1}$ from February 1994 to March 1995 (Gast et al. unpubl.). The variation in open water between the sampling days ( 5 to $7.2 \times 10^{5} \mathrm{ml}^{-1}$; Figs. $2 \& 3 \mathrm{~A}$ ) was in the normal. range for these waters. There was considerable variation through time, which was mainly due to changes of the variables in the larger oceanic water mass that passed the island. Variations in microbial variables and nutrients through time and between sev- eral stations along the coast of Curaçao are treated elsewhere (Gast et al. unpubl). Here we focus on the (patterns in) differences between the water types we studied: oceanic open versus reef overlying water and the 3 water types in the reef water column: overlying, bottom and crevice water.

The bacterial numbers in reef overlying water and adjacent open water (Figs. 2 to $4, x$-axis) were in the range ( 3 to $9 \times 10^{5} \mathrm{ml}^{-1}$ ) found generally in the water column over coral reefs and in the adjacent oceanic open water (Moriarty 1979, Landry et al. 1984, Moriarty et al. 1985b, Rose \& Risk 1985, Linley \& Koop 1986, Ducklow 1990, Herndl 1991, Yoshinaga et al. 1991, Rath et al. 1993, Ayukai 1995, Torréton \& Dufour $1996 \mathrm{a}, \mathrm{b})$. Higher values (>2 $\times 10^{6}$ ) have been reported, but these apply to regions that are not comparable to the fringing reefs at Curaçao, i.e. in lagoons (Torréton \& Dufour 1996a, b) or water close to mangrove forests (Herndl 1991). Considering the narrowness of our fringing reefs $(50$ to $150 \mathrm{~m}$ ) and the average aceanic currents of 30 to $50 \mathrm{~cm} \mathrm{~s}^{-1}$ (US Navy current charts), we suppose that water movement prevents large deviations from the values in the oceanic water.

We found lower numbers of bacteria in reef overlying water than in the adjacent oceanic water in January at Stns 1 and 2, but not at Stn 4 (Figs. 2 \& 3A). We 


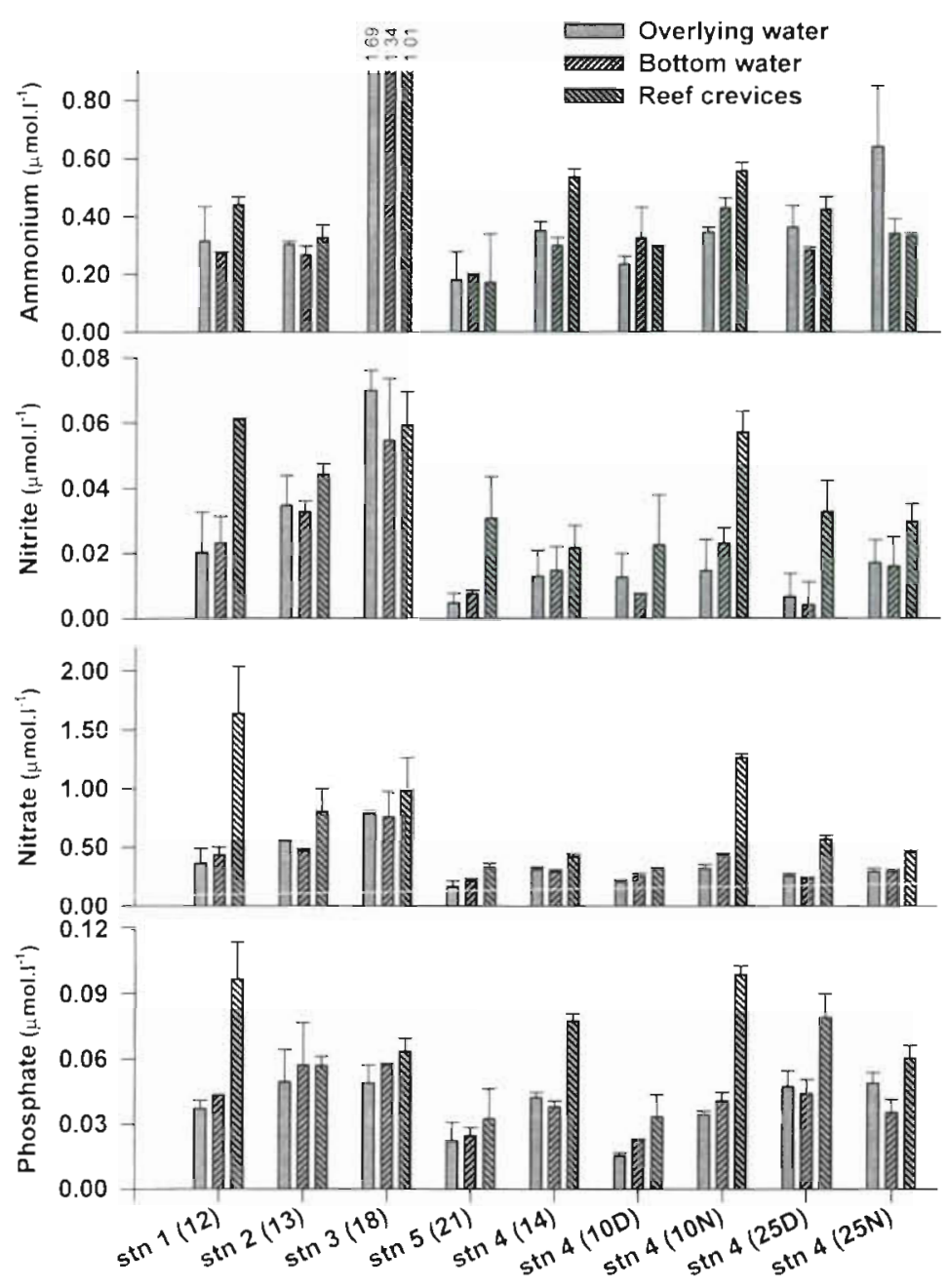

Fig. 5. Nutrient concentrations in January 1995 at Stns 1 to 5 (see Fig. 1) in overlying water at $2 \mathrm{~m}$ depth, bottom water and in reef crevices. Labels on horizontal axis indicate station number with day in January 1995 in parentheses; $\mathrm{D}$ (day) $=\mathrm{ca} 10: 00 \mathrm{~h}, \mathrm{~N}$ (night) $=\mathrm{ca} 22: 00 \mathrm{~h}$. Means + SD of duplicate samples (50 $\mathrm{m}$ apart) at each site ( 4 measurements in each sample) are shown

took notes on weather and sea conditions each sampling day, which show rougher sea when we sampled Stn 4 . During a separate study at Curaçao, we found consistently lower bacterial densities at 3 reef sites than in oceanic water for 6 mo (Gast et al. unpubl.). A reduction of bacterial numbers in subsurface waters over coral reefs compared to the adjacent open water has been found at many reefs in the Pacific (Moriarty 1979. Moriarty et al. 1985b, Linley \& Koop 1986, Ayukai 1995, Torréton \& Dufour 1996b). There is large variation in the extent of the difference between reef water and the adjacent open water both among and within our study and the other ones mentioned, most likely due to variations in water movement. All the studied sites, at Curaçao as well as those at reefs in the Pacific, are subject to strong influences of current and surge. However, the general phenomenon is clear: bacterial numbers are reduced over coral reefs.

We looked in greater detail at what is commonly called coral reef water, by distinguishing among various water types. As there were hardly differences between overlying water at $2 \mathrm{~m}$ depth and bottom water (Figs. 2 to 5), it appears that the water column over our fringing reefs was usually well mixed. Only in June 1994 did we find a clear and consistent reduction of bacteria towards the bottom (Fig. 2). In this perioct the sea was almost flat and there was little current. In contrast, from January to April 1995, when the same numbers were found throughout the water column, there was considerably more wind and surge. Thorough mixing of the water column clearly prevented the establishment of a gradient from overlying water to bottom water The clearest reduction of bacteria was in reef crevices, where water movement is most restrained. With a few exceptions, the number of bacteria was always reduced in crevices compared to the surrounding reef water (Figs. 2 to 5 ).

Aside from the physical circumstances, the structure of the reef was a relevant factor. At Stn 1 crevices are extensive and deep with a corresponding longer water residence time. The reduction of bacteria was consistent and depended very little on the roughness of the sea (Figs. 3A, B \& 4; rough seas occurred on February 14). At Stn 2, with a moderately developed reef, a substantial decrease in bacterial numbers in reef crevices was often observed (Figs. 3A \& 4), but not on a rough day, February 14 (Fig. 3B). At Stn 3 no difference occurred in February or on April 4. Reduced numbers occurred in March and on April 19, but to a smaller extent than at the other sites (Fig. 4). Corals are small and thinly distributed at this site. The crevices that orrur are small, relatively open and water movement can easily mix the crevice water. The pattern which appears is that the difference in bacterial numbers between crevices and the surrounding bottom water was both more consistent and larger in welldeveloped than in degenerated reefs. Reefs with. a high relief have a thicker boundary layer with reduced water movement, and patterns in microbial variables are more easily established than on reefs with small corals where mixing of bottom and crevice water is extensive

We are not aware of any other study on bacterial variables in the specific small-scale water types we 

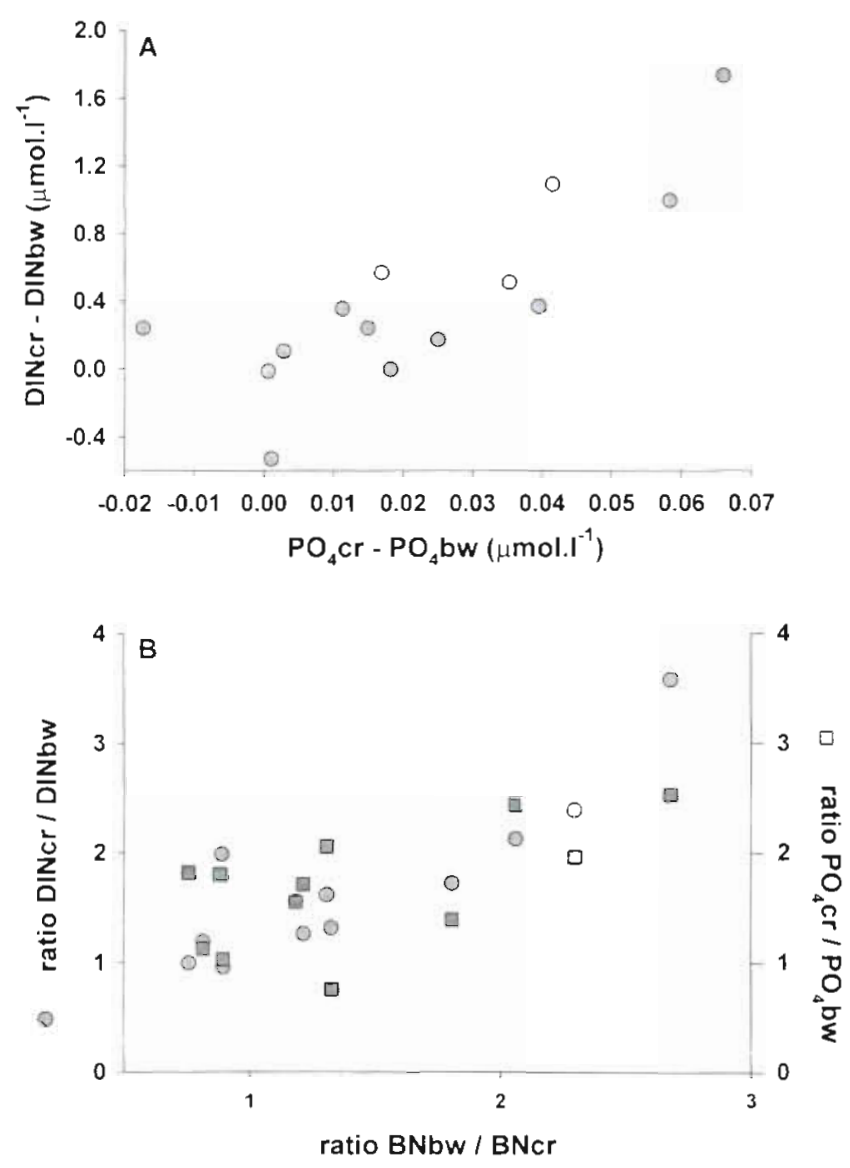

Fig. 6. (A) Increase of nutrients in reef crevices (cr) compared to the adjacent bottom water (bw): $\mathrm{PO}_{4}{ }^{3-}$ versus DIN $\left(\mathrm{NH}_{4}{ }^{-}+\right.$ $\mathrm{NO}_{2}{ }^{-}+\mathrm{NO}_{3}{ }^{-}$). Concentration in bottom water is subtracted from concentration in crevice water; a positive value indicates a higher value in crevice water Shown are samples from all stations, taken in January 1995. (B) Reef crevices compared to the adjacent bottom water decrease in bacterial numbers versus increases in $\mathrm{PO}_{4}{ }^{3-}$ and DIN. Bacterial number in bottom water is divided by bacterial number in crevice water; a ratio $>1$ indicates lower density in crevice water Concentrations of DIN and $\mathrm{PO}_{4}{ }^{3-}$ in crevice water are divided by concentrations in bottom water; a ratio $>1$ indicates a higher concentration in crevice water. Shown are samples taken at Stns 1, 2, 4 and 5 in January 1995

sampled, but there are comparable aspects in the time series by Linley \& Koop (1986). They sampled at $20 \mathrm{~cm}$ water depth during a tidal cycle at One Tree Island (Great Barrier Reef) 1 d before spring tide. At low tide corals on the reef flat are in $10 \mathrm{~cm}$ water or less (A. Salih pers. comm.) and Linley \& Koop must have sampled between the corals, which is what we defined as bottom water. At high tide, there was a 2 to $3 \mathrm{~m}$ water column over the reef (Frith 1981) and they sampled what we call overlying water. At 5 reef sites, Linley \& Koop (1986) found decreasing bacterial numbers from high to low tide, which agrees with our observations of reduced bacterial numbers in bottom and crevice water compared to the overlying water.

The question remains why bacteria disappeared in bottom water and reef crevices. That the strongest reduction of bacterial numbers occurred in reef crevices indicates that filter-feeding reef benthic organisms removed the bacteria from the water. Sponges pump large amounts of water (Reiswig 1974) and efficiently filter bacteria from this water (Reiswig 1971, 1975, Wilkinson 1978, Pile et al. 1996, 1997). Sponges are abundant on the reefs of Curaçao (van Soest 1984). They were present in virtually all crevices (authors' pers. obs.) and are likely candidates for causing the observed reduction in bacteria.

\section{Bacterial growth rates}

The growth rates at Curaçao (20 to $140 \mathrm{~h}$ generation times) were in the range found (with various methods) at Davies Reef (Ducklow 1990), Lizard Island (Moriarty et al. 1985b), One Tree Island (Linley \& Koop 1986) and Tikehau (Torréton \& Dufour 1996b). We never saw the extreme short ( 2 to $5 \mathrm{~h}$ ) or long ( 240 to $384 \mathrm{~h}$ ) generation times also reported. These extreme values could reflect differences in, for example, methodology, food availability or physical conditions.

Enhanced specific bacterial growth rates in reef crevices and bottom water occurred mostly in parallel with a reduction in numbers (Figs. $2 \& 3$ ), showing the same dependence on water movement and reef structure. Bacterial growth was often enhanced in reef crevices and in June 1994, with a flat sea, also in bottom water. A possible food source for enhanced bacterial growth in crevices could be accumulation of trapped organic particles. However, many openings of crevices were sideways rather than up and the equal growth rates in bottom water and crevices during quiet conditions in June do not support this hypothesis. Such particle accumulation is more likely to be of importance on reefs in quiet waters in bays and lagoons. We suggest that the bacteria were stimulated by food sources excreted by the reef, such as coral mucus (Herndl \& Velimirov 1986, Paul et al. 1986, Schiller \& Herndl 1989), when water movement did not immediately dilute this food away.

The overall pattern that appears is that bacterial growth is stimulated in both reef bottom water and crevices and that the strongest removal of bacteria takes place in crevices (June data, Fig 2). The causing mechanisms behind these 2 phenomena are different, but the physical circumstances determine each pattern so strong that they often occur parallel. Although bacterial specific growth rates were at times increased in reef crevices, the densities of those bacteria were 
clearly reduced. This shows that bacteria were removed faster from the water than new cells were formed by cell division. Enhanced growth did not compensated for loss of bacterial cells. This indicates a net influx of organic carbon and nutrients in the form of bacteria into the reef, notably in reef crevices.

\section{Nutrients}

Ammonium, nitrite, nitrate and phosphate were enhanced in reef crevices (Fig. 5). The increases in DIN $\left(\mathrm{NH}_{4}{ }^{-}+\mathrm{NO}_{2}{ }^{-}+\mathrm{NO}_{3}{ }^{-}\right)$and DIP were proportional in a N:P ratio of 24 (Fig. 6A). This is close to the Redfield ratio and indicates mineralization as the most probable source of these nutrients, either by heterotrophic organisms, such as sponges (Corredor et al. 1988, Pile 1996, Diaz \& Ward 1997) and fish (Meyer \& Schuitz 1985), or in the reef bottom interstitial water (Sansone et al. 1988, Tribble et al. 1994). Groundwater of Curaçao contains high concentrations of nitrate, but it seems unlikely that much seeps out with only $20 \mathrm{~mm}$ rainwater addition per year and considerable subtraction for irrigation (Louws et al. 1998). Moreover, our data do not indicate extensive groundwater seepage, as nitrate concentrations and N:P ratios would have been much higher.

Both DIN and $\mathrm{PO}_{4}{ }^{3-}$ were increased when bacterial numbers were decreased in most samples (Fig. 6B). Bacteria can be considered as organic nitrogen and phosphorus in particulate form. Assuming that those bacteria were consumed by filter feeders, we can calculate the amounts of nutrients those filter feeders could excrete as a result of mineralization of these bacteria. We assume for the bacteria a carbon content of $20 \mathrm{fg} C$ per cell (Lee \& Fuhrman 1987), a C:N:P ratio of 45:10:1 (Zweifel et al. 1993) and 20\% growth efficiency for the filter feeders (Thomassen \& Riisgård 1995). Thus $N \times 20 / 12=$ fmolC followed by fmolC/4.5 $=f m o l N$ and $f m o l C / 45=f m o l P$, giving the amount of $\mathrm{N}$ and $\mathrm{P}$ the removed bacteria contained. After multiplication by $1-0.2=0.8$ for the assumed growth efficiency of sponges these amounts of $\mathrm{N}$ and $\mathrm{P}$ are compared to the measured concentrations in bottom water minus those in crevices. This calculation shows that a considerable fraction of the increase in inorganic nutrients could be explained by the decrease in bacterial numbers: $11 \%$ (range 5 to $23 \%, \mathrm{SD}=6 \%, \mathrm{n}=9$ ) of $\mathrm{N}$ and $21 \%$ (range 7 to $49 \%, \mathrm{SD}=16 \%, \mathrm{n}=7$ ) of $\mathrm{P}$. Filter feeders consume many other organisms than bacteria such as algae, flagellates, ciliates and zooplankton, but this calculation shows that uptake and mineralization of bacteria could potentially form an important part of the nutrient enhancement in coral reef crevices. Further study is clearly needed to dis- tinguish coral effects such as crevice shape, mineralization of other plankton and excretion of nutrients by hiding or resting fish.

In conclusion, our data show that bacteria are an important group in the local process of carbon and nutrient transfer in coral reef ecosystems. They are removed from the water column and at the same time their growth is stimulated, probably by the coral reef benthos. These patterns are most clearly and consistently established in reef crevices. The extent to which these gradients can be recognized depends both on water movement and on the structural development of the coral reef. Mineralization of the consumed bacteria could to a considerable extent explain increases in nutrients in reef crevices.

Acknowledgements. The research was funded by the Netherlands Institute for Sea Research (NIOZ). We thank the Carmabi Foundation for logistical support and Frank Isabella, Oscar Franz and Brian Leysner for their assistance in the field. We thank Karel Bakker, Jan van Ooijen and Annet van Koutrik (NIOZ) for measuring the nutrients. We thank Stephen Smith (University of Hawaii) for comments on the manuscript. This is NrOZ pubiication no. $32 \% 1$

\section{LITERATURE CITED}

Ayukai T (1995) Retention of phytoplankton and planktonic microbes on coral reefs within the Great Barrier Reef, Australia. Coral Reefs 14:141-147

Bjornsen PK, Kuparinen J (1991) Determination of bacterioplankton biomass, net production and growth efficiency in the Southern Ocean. Mar Ecol Prog Ser 71:185-194

Buth L, Ras J (1992) Inventory of the land-based sources of marine pollution in the Netherlands Antilles. Dept of Public Works of Curaçao and Environmental Service Curaçao; prepared for CEPPOL Program, IOC-UNEP CAR/RCU

Corredor JE, Wilkinson CR, Vincente VP, Morell JM, Otero O (1988) Nitrate release by Caribbean reef sponges. Limnol Oceanogr 33:114-120

Diaz MC, Ward BB (1997) Sponge-mediated nitrification in tropical benthic communities. Mar Ecol Prog Ser 156: 97-107

Ducklow HW (1990) The biomass, production and fate of bacteria in coral reefs. In: Dubinsky $Z$ (ed) Coral reefs. Elsevier, Amsterdam, p 265-290

Fenchel T (1988) Marine plankton food chains. Annu Rev Ecol Syst 19:19-38

Ferrier-Pagès C, Gattuso JP (1998) Biomass, production and grazing rates of pico- and nanoplankton in coral reef waters (Miyako Island, Japan). Microb Ecol 35:46-57

Frith CA (1981) Circulation in a platform reef lagoon, One Tree Reef, Southern Great Barrier Reef. Proc 4th Int Coral Reef Symp, Manila 1:347-354

Grasshoff K (1983) Methods in seawater analysis. Verlag Chemie, Weinheim

Hatcher BG (1997) Organic production and decomposition. In: Birkland C (ed) Life and death of coral reefs. Chapman \& Hall, New York, p 140-174

Helder W, Vries RTP (1979) An automatic phenol-hypochlorite method for determination of ammonia in sea- and brackish waters. Neth J Sea Res 13:154-160

Herndl GJ (1991) Microbial biomass dynamics along a trophic 
gradient at the Atlantic barrier reef off Belize (Central America) Mar Ecol 12:41-51

Herndl GJ, Velimirov B (1986) Microheterotrophic utilization of mucus released by the Mediterranean coral Cladocora cespitosa. Mar Biol 90:363-369

Hobbie JE, Daley RJ, Jasper S (1977) Use of Nuclepore filters for counting bacteria by epilluorescence microscopy. Appl Environ Microbiol 33:1225-1228

Landry MR, Haas LW, Fagerness VL (1984) Dynamics of microbial plankton communities: experiments in Kaneohe Bay, Hawaii. Mar Ecol Prog Ser 16:127-133

Lee S, Fuhrman JA (1987) Relationships between biovolume and biomass of naturally derived marine bacterioplankton. Appl Environ Microbiol 53:1298-1303

Linley EAS, Koop K (1986) Significance of pelagic bacteria as a trophic resource in a coral reef lagoon, One Tree Island, Great Barrier Reef. Mar Biol 92:457-464

Louws RJ, Vriend SP, Frapporti G (1998) De grondwaterkwaliteit van Curaçao (The groundwater quality of Curaçao; abstract in English). $\mathrm{H}_{2} \mathrm{O} 26: 788-791$

Meyer JL, Schultz ET (1985) Tissue condition and growth rate of corals associated with schooling fish. Limnol Oceanogr 30:157-166

Moriarty DJW (1979) Biomass of suspended bacteria over coral reefs. Mar Biol 53:193-200

Moriarty DJW, Pollard PC, Alongi DM, Wilkinson CR, Gray JS (1985a) Bacterial productivity and trophic relationships with consumers on a coral reef (Mecor I). Proc 5th Int Coral Reef Symp, Tahiti 3:457-462

Moriarty DJW, Pollard PC, Hunt WG (1985b) Temporal and spdilid variation in bacterial production in the water column over a coral reef. Mar Biol 85:285-292

Murphy J, Riley J (1962) A modified single solution method for the determination of phosphate in natural waters. Analyt Chim Acta 27:31-36

Paul JH, DeFlaun MF, Jeffrey WH (1986) Elevated levels of microbial activity in the coral surface microlayer. Mar Ecol Prog Ser 33:29-40

Pile A.J (1996) The role of microbial food webs in benthicpelagic coupling in freshwater and marine ecosystems. PhD thesis, College of William and Mary, Williamsburg, VA

Pile AJ, Patterson MR, Savarese M, Chernykh VI. Fialkov VA (1997) Trophic effects of sponge feeding within Lake Baikal's littoral zone. 2. Sponge abundance, diet, feeding efficiency, and carbon flux. Limnol Oceanogr 42:178-184

Pile AJ, Patterson MR, Witman JD (1996) In situ grazing on plankton $<10 \mu \mathrm{m}$ by the boreal sponge Mycale lingua. Mar Ecol Prog Ser 141:95-102

Rath J, Schiller C, Herndl GJ (1993) Ectoenzymatic activity and bacterial dynamics along a trophic gradient in the caribbean Sea. Mar Ecol Prog Ser 102:89-96

Reiswig HM (1971) Particle feeding in natural populations of three marine demosponges. Biol Bull (Woods Hole) 141: $568-591$

Reiswig HM (1974) Water transport, respiration and energetics of three tropical manne sponges. J Exp Mar Biol Ecol $14: 231-249$

Editorial responsibility: Otto Kinne (Editor),

Oldendorf/Luhe, Germany
Reiswig HM (1975) Bacteria as food for temperate-water marine sponges. Can J Zool 53:582-589

Rose CS, Risk MJ (1985) Increase in Cliona delitrix infestation of Montastrea cavernosa heads on an organically polluted portion of the Grand Cayman fringing reef. PSZN I: Mar Ecol 6:345-363

Sansone FJ, Andrews CC, Buddemeier RW, Tribble GW (1988) Well-point sampling of reef interstitial water. Coral Reefs $7: 19: 22$

Schiller C. Hernd] GJ (1989) Evidence of enhanced microbial activity in the interstitial space of branched corals: possible implications for coral reef metabolism. Coral Reefs 7: $179-184$

Simon M, Azam F (1989) Protein content and protein synthesis rates of planktonic marine bacteria. Mar Ecol Prog Ser $51: 201-213$

Sokal RR, Rohlf FJ (1995) Biometry. WH Freeman and Company, New York

Sorokin Y (1990) Aspects of trophic relations, productivity and energy balance in coral-reef ecosystems. In: Dubinsky $Z$ (ed) Coral reefs. Elsevier, Amsterdam, p 401-410

Sorokin YI (1973) On the feeding of some scleractinian corals with bacteria and dissolved organic matter. Limnol Oceanogr 18:380-385

Sorokin YI (1993) Coral reef ecology. Springer Verlag, Berlin

Thomassen S, Riisgård HU (1995) Growth and energetics of the sponge Halichondra panicea. Mar Ecol Prog Ser 128: $239-246$

Torréton JP, Dufour P (1996a) Bacterioplankton production determined by DNA synthesis, protein synthesis, and frequency of dividing cells in Tuamotu atoll lagoons and surrounding ocean. Microb Ecol 32:185-202

Torréton JP, Dufour P (1996b) Temporal and spatial stability of bacterioplankton biomass and productivity in an atoll lagoon. Aquat Microb Ecol 11:251-261

Tribble GW, Atkinson MJ, Sansone FJ, Smith SV (1994) Reef metabolism and endo-upwelling in perspective. Coral Reefs 13:199-201

van Duyl FC (1985) Atlas of the living reefs of Curacao and Bonaire (Netherlands Antilles). Foundation for Scientific Research in Surinam and the Netherlands Antilles, Utrecht

van Soest RWM (1984) Marine sponges from Curaçao and other Caribbean localities. Foundation for Scientific Research in Surinam and the Netherlands Antilles, Utrecht

Wilkinson CR (1978) Microbial associations in sponges. I. Ecology, physiology and microbial populations of coral reef sponges. Mar Biol 49:161-167

Yoshinaga I, Fukami K, Ishida Y (1991) Comparison of DNA and protein synthesis rates of bacterial assemblages between coral reef waters and pelagic waters in tropical ocean. Mar Ecol Prog Ser 76:167-174

Zweifel UL, Norrman B, Hagström Å (1993) Consumption of dissolved organic carbon by marine bacteria and demand for inorganic nutrients. Mar Ecol Prog Ser 101: $23-32$

Submitted: March 25, 1997; Accepted: October 15, 1997

Proofs received from author(s): May 28, 1998 